\title{
ENVIRONMENTAL CHANGE AND HUMAN IMPACTS ON TERRESTRIAL ECOSYSTEMS OF THE SUB-ANTARCTIC ISLANDS BETWEEN THEIR DISCOVERY AND THE MID-TWENTIETH CENTURY
}

\author{
by Peter Convey and Marc Lebouvier
}

(with two text-figures, two tables and two plates)

\begin{abstract}
Convey, P. \& Lebouvier, M. 2009 (11:xii): Environmental change and human impacts on terrestrial ecosystems of the sub-Antarctic islands between their discovery and the mid-twenticth century. Papers and Proceedings of the Royal Society of Tasmania 143(1): 33-44. https://doi.org/10.26749/rstpp.143.1.33 ISSN 0080-4703. British Antarctic Survey, Natural Environment Research Council, High Cross, Madingley Road, Cambridge CB3 •ET, United Kingdom (PC*); UMR 6553 CNRS, Université de Rennes 1, Station Biologique, F 35380 Paimpont, France (ML). *Author for correspondence. Email: pcon@bas.ac.uk
\end{abstract}

\begin{abstract}
Sub-Antarctic islands share many similarities in their history of human interaction and impacts before the mid-twentieth century. Large impacts on land were associated with the marine exploitation industries of sealing and whaling. Their onshore activities involved considerable construction and pollution in many accessible landing bays, inevitably destroying large areas of coastal terrestrial habitat. Considerable transfer of nutrients to terrestrial environments will have been associated with scavengers utilising large carrion supplies. Attempted establishment of agricultural industries, particularly the introduction of grazing mammals, took place on several islands and, although rarely proving economically viable, often resulted in the long-term creation of feral populations. These were accompanied by introductions of other alien vertebrates, plants and invertebrares to most sub-Antarctic islands, although precise records of introduction events, or subsequent biological studies in this period, largely do not exist. Thus, exploitation industries in this region inevitably led to considerable alterations and impacts to terrestrial ecosystems almost from the outset of human contact with the islands. In the absence of baseline ecological and biodiversity studies, the true magnitude of many of these impacts is difficult to assess, although their legacy continues to the present day. Indeed, the almost complete removal of fur seals may have allowed coastal vegetation to become more extensive and lush than hitherto, paradoxically now regarded as "typical" and threatened by recovery of seal populations.
\end{abstract}

Key Words: non-indigenous species, nutrient transfer, habitat loss, ecosystem engineering, whaling, sealing, herbivore, predator.

\section{INTRODUCTION}

The sub-Antarctic islands lie isolated from continental landmasses in the Southern Ocean. In a terrestrial biological context, a core group of sub-Antarctic islands is often recognised, unified by general similarities in climate and the presence or absence of certain groups of flora or fauna (Selkirk 2007). This core group includes South Georgia, the PrinceEdward Islands, Îles Kerguelen, Archipel Crozet, Heard and McDonald Islands, and Macquarie Island. These islands lie close to the oceanic Antarctic Polar Frontal Zone, and typically have cold, cloudy and windy climates, with limited temperature variation year-round (Smith 1984, Convey 1996, 2007a, Pendlebury \& Barnes-Keoghan 2007). Only two islands (South Georgia and Heard Island) are heavily glaciated today, with Îles Kerguelen also having glaciers and an icecap in its western part. Many of these islands are currently impacted by contemporary trends of climate change (Convey 2007a, Pendlebury \& Barnes-Keoghan 2007, le Roux 2008), but such impacts lie outside the scope of the current paper. The anthropogenic factors underlying current global environmental change are generally accepted to have commenced during the Industrial Revolution of the nineteenth century, and their impacts have accelerated since the second half of the twentieth century. There appears to be no suggestion of detectable impacts of this process during the earlier phases of occupation and exploitation of the sub-Antarctic islands in the nineteenth and first half of the twentieth centuries (e.g., for South Georgia see fig. 4 in Cook et al. unpubl., based on data extracted from Turner $e t a l$. 2004), al though this may be largely because few appropriate research or monitoring data sets exist from this period.
A range of other islands, both south and north of this core group, are also referred to in some literature as sub- or peri-Antarctic. These include the South Sandwich, South Orkney and South Shetland archipelagos along the Scotia arc, properly forming part of the maritime Antarctic terrestrial biogeographic zone (Smith 1984, Convey 2007b), and the cool temperate Diego Ramírez Island (Chile), Île Amsterdam and Ile Saint-Paul in the Indian Ocean, the Tristan da Cunha group and Gough Island in the Atlantic Ocean, and the "New Zealand shelf islands" (Antipodes, Campbell, Auckland, Bounty). The maritime Antarctic archipelagos have much reduced floral and invertebrate diversity, while the cool temperate islands differ from the "core" sub-Antarctic grouping primarily in the inclusion of significant stands of woody plants in their flora, but share with them the development of a "megaherb" flora and the lack of native terrestrial mammals. As these islands have many similarities in their history of human discovery, occupation and exploitation, all are included, where appropriate, amongst the information presented in this paper.

Sub-Antarctic floras and faunas typically do not include many taxonomic and functional groups familiar from lower latitudes. Plant communities, except on the more northern islands not included in the core sub-Antarctic grouping, do not include woody plants or species requiring insect pollination (Convey et al. 2006a). Megaherbs, often endemic to particular islands, are a dominant feature of many communities, whose evolution is linked with the absence of native vertebrate herbivores (Meurk et al. 1994, Mitchell et al. 1999, Convey 2007a, b). There are no native land mammals, reptiles or amphibians and very few nonmarine birds. A large element of the global profile of the 
sub-Antarctic islands is generated by their hosting significant populations of "charismatic" marine vertebrates (seals, penguins, albatrosses, petrels, etc; Woehler et al. 2001). Their native terrestrial faunas comprise primarily arthropods (mites, springtails, spiders, beetles, flies and moths, with smaller representation of some other insect groups), and tardigrades, nematodes, rotifers, enchytraeids, earthworms and molluscs (Gressitt 1970, Greenslade 2006, Convey $2007 \mathrm{a}, \mathrm{b})$. There are no large invertebrate predators, and predation is likely to be an insignificant ecological pressure in indigenous communities. While detritivores appear to numerically dominate these invertebrate communities, decay processes are slow (Slabber \& Chown 2002).

Sub-Antarctic terrestrial ecosystems are simple in comparison with most ecosystems globally, and are thought to lack functional redundancy. This raises the possibility of new colonists (whether arriving by natural means or with human assistance) occupying new ecological niches, which could fundamentally change the structure and function of trophic webs. Indigenous sub-Antarctic species and communities appear to be particularly vulnerable to invading predators and species with higher competitive abilities (Frenot et al. 2005, 2008, Convey et al. 2006b).

\section{DISCOVERY AND EXPLOITATION}

\section{Initial exploitation}

The first sightings of some of the more northern islands were made during the sixteenth and seventeenth centuries. These sightings, however, did not result in landings, repeat visits, or establishment of settlements or industrial activity. For instance, there are no further sightings of South Georgia known between that of 1675 and Cook's visit in 1775 (Headland 1984) and, while Île Amsterdam was discovered in 1522 by S. Del Cano on one of Magellan's ships, the first known landing is attributed to W. de Vlaming in 1696 (Lebouvier \& Frenot 2007). The majority of islands were discovered between the latter part of the eighteenth and the early nineteenth centuries (table 1). There is archaeological evidence on Auckland Island of earlier (c. 1200) Polynesian discovery and, possibly, settlement (Anderson 2006, 2009, Dingwall 2007).

The primary focus of those who discovered all of the sub-Antarctic islands lay with territorial and economic gain (table 1). In this context the rich marine vertebrate life of the Southern Ocean and its constituent islands was

TABLE 1

History of discovery, human occupation and major industrial uses of various sub- and peri-Antarctic islands before $c .1950^{1}$

\begin{tabular}{|c|c|c|c|}
\hline & $\begin{array}{l}\text { Date of discovery } \\
\text { (discoverer) }\end{array}$ & $\begin{array}{l}\text { Presence of permanent } \\
\text { settlements in } 21 \text { st century }\end{array}$ & $\begin{array}{c}\text { Industrial operations and } \\
\text { other human influences }\end{array}$ \\
\hline Diego Ramírez (Chile) & 1619 (Ramirez) & No & Meteorological station established 1957 \\
\hline South Georgia & 1675 (de la Roché) & Yes & $\begin{array}{l}\text { Seal and penguin hunting, whaling (land-based stations } \\
1904-1965) \text {, research expeditions }\end{array}$ \\
\hline $\begin{array}{l}\text { South Sandwich } \\
\text { Islands }\end{array}$ & 1775 (Cook) & No & Sealing \\
\hline South Orkney Islands & $\begin{array}{l}1821 \text { (Palmer, } \\
\text { Powell) }\end{array}$ & Yes & $\begin{array}{l}\text { Sealing, whaling (land-based station, Signy Island, in } \\
\text { 1920s), meteorology/research station (Laurie Island, est. } \\
\text { 1903), WWII operations, subsequently research (Opera- } \\
\text { tion Tabarin; Falkland Islands Dependencies Survey) }\end{array}$ \\
\hline South Shetland Islands & $\begin{array}{l}1599 \text { (Gerritsz) } \\
1603 \text { (de Castilla) }\end{array}$ & Yes & Sealing, whaling (land-based station, Deception Island) \\
\hline $\begin{array}{l}\text { Marion and Prince } \\
\text { Edward Islands }\end{array}$ & 1663 & Yes & Sealing, guano collection \\
\hline Îles Kerguelen & $\begin{array}{l}1772 \text { (de Kerguelen } \\
\text { de Trémarec) }\end{array}$ & Yes & $\begin{array}{l}\text { Whaling (land-based station), farming (Sheep, Mouflon, } \\
\text { Reindeer) }\end{array}$ \\
\hline Archipel Crozet & $\begin{array}{l}1772 \text { (Marion- } \\
\text { Dufresne) }\end{array}$ & Yes & Sealing, whaling, shipwrecked castaways \\
\hline Île Amsterdam & 1522 (Del Cano) & Yes & Farming (cattle), shipwrecked castaways \\
\hline $\begin{array}{l}\text { Heard and Mcdonald } \\
\text { Islands }\end{array}$ & $1833(\mathrm{Kemp})$ & No & $\begin{array}{l}\text { Sealing, scientific station } 1947-1955 \text {, temporary scientific } \\
\text { camps since } 1955\end{array}$ \\
\hline Macquarie Island & 1810 (Hasselburgh) & Yes & $\begin{array}{l}\text { Seal and penguin hunting, Australian Antarctic Expedi- } \\
\text { tion and meteorological station } 1911-1915 \text {, research } \\
\text { station est. } 1948\end{array}$ \\
\hline Antipodes Islands & 1800 (Waterhouse) & Yes & $\begin{array}{l}\text { Sealing, farming (cattle, failed), "castaway" depot } \\
\text { including release of goats, evidence of earlier Polynesian } \\
\text { presence }\end{array}$ \\
\hline Auckland Islands & 1806 (Bristow) & yes & $\begin{array}{l}\text { Whaling, sealing, farming (fax), emergency "castaway" } \\
\text { depots for shipwreck victims, } 1868-1926 \text {, including } \\
\text { release of rabbits, cattle, pigs and goats, cattle also tempo- } \\
\text { rarily farmed, evidence of earlier Polynesian presence }\end{array}$ \\
\hline Bounty Islands & 1788 (Bligh) & No & Sealing \\
\hline Campbell Island & 1810 (Hasselburgh) & Yes & $\begin{array}{l}\text { Sealing, whaling, farming (sheep, cattle), "castaway" de- } \\
\text { pots including release of goats, coastguard and meteoto- } \\
\text { logical station est. WWII, closed } 1995\end{array}$ \\
\hline
\end{tabular}

${ }^{1}$ See also Cumpston 1968, Headland 1984, McIntosh \& Walton, 2000, Fell 2002, Frenot et al. 2005, Taylor 2006, Bergstrom \& Selkirk 2007, Russ 2007, Cooper 2008, Terauds \& Stewart 2008). 
quickly recognised as an economic bonanza. Sealing was the first exploitation industry active in the region, with uncontrolled harvesting of fur seals for their valuable pelts following within years of each island's discovery (Trathan \& Reid 2009). This quickly and inevitably brought the target stocks near to extinction and led to the demise of the industry itself at most locations by the early decades of the nineteenth century, although limited population recoveries at some locations were followed by further short periods of sealing activity later in the century (e.g., on South Georgia; Headland 1984). On South Georgia, Heard and Macquarie islands, Southern Elephant Seals, Mirounga leonina (Linnaeus, 1758), were exploited for their oil, as were penguins on Macquarie and Auckland islands (see also Townrow 1988).

As demand for oil increased throughout the nineteenth century, the whaling industry developed, first in the Northern Hemisphere and then in the south. At first the smaller whales (Southern Right Whale, Eubalaena australis (Desmoulins, 1822) and Humpback Whale, Megaptera novaeangliae (Borowski, 1781)) were captured but, with the invention of the harpoon gun with its explosive head in 1864 the larger rorquals could be hunted. By the early twentieth century, the construction of shore-based whaling stations on some sub- and peri-Antarctic islands (e.g., South Georgia, Îles Kerguelen, Signy Island, Deception Island, Falkland Islands) as well as the southern continents, taking advantage of high local densities of whales, led to the rapid and again uncontrolled exploitation of the stocks of great whales. Towards the end of the whaling period the entire whale was processed and rendered down while, as whales became rarer, the emphasis shifted to the development of pelagic whaling and processing at sea, heralding the closure of land-based whaling stations. The larger species were exhausted first, with over-exploitation progressively moving to smaller species (see Basberg (2004) and Hart (2006) for a history of the whaling industry on South Georgia and in the South Atlantic Falkland Islands Dependencies).

\section{Farming}

The inclement and cold climate of most sub-Antarctic islands precluded the possibility of the establishment of economically viable onshore farming industries, and no exploitation of terrestrial biological or geological resources has taken place other than the use of various marine birds for food for station staff, and the industrial-scale collection of penguins for use as fuel in whale and seal oil digesters. However, on the more northern islands (Île Amsterdam and the New Zealand shelf islands), as well as on Îles Kerguelen, there were concerted attempts at the establishment of livestock (Domestic Cattle, Bostaurus Linnaeus, 1758, sheep, Ovis aries Linnaeus, 1758), and there were occasional and unsuccessful attempts at crop cultivation on some of the New Zealand islands (table 1). In some instances livestock were effectively kept to a restricted area (e.g., paddock, offshore island), while in others they were simply allowed to roam free. Other vertebrates were deliberately introduced, at least as human commensal/ companion animals, to most islands where long-term settlements were established (including industrial operations and, towards the end of the period under review, scientific research stations) (table 2). These included Domestic Dogs, Canis familiaris Linnaeus, 1758 (primarily as sledge dogs on the southern islands), and Domestic Cats, Felis catus Linnaeus, 1758, the latter then released or escaping to form feral populations on many islands as part of abortive attempts to control expanding mouse, rat and/or European Rabbit, Oryctolagus cuniculus (Linnaeus, 1758), populations. Smaller numbers of stock and working animals (chickens, Gallus gallus Linnaeus, 1758, pigs, Susscrofa Linnaeus, 1758, horses, Equus caballus Linnaeus, 1758) were also associated with human occupation, although generally not having any direct impact on the local environment beyond the boundaries of settlements. Significant herds of feral grazing mammals were established on South Georgia (Reindeer, Rangifer tarandus Linnacus, 1758, imported originally to provide "sport" for the whaling station managers; Leader-Williams 1988), Kerguelen (Reindeer, Mouflon, Ovis musimon Pallas, 1762, again for sport), Île Amsterdam (cattle; Chapuis et al. 1994) and various of the New Zealand shelf islands (tables 1,2). In recognition of the fact that castaway survivors of shipwrecks were a frequent feature on the more northern islands, the responsible national governments also established a network of stocked depots and huts, additionally releasing animals (including rabbits, goats, Capra hircus Linnaeus, 1758, pigs, cattle) on some to provide a feral source of food to assist survivors (table 1; see, for example, Fraser 1986, Allen 1997). Shipwreck survivors also exploited any available local sources of food, in particular targeting breeding birds such as penguins, although these impacts would have been minor except at a very local scale.

\section{Inadvertent introductions}

An associated impact of the requirements to support these livestock, and supply the human community, was the import of animal fodder, human foodstuffs and vast quantities of general cargo. Although the risks and possible consequences were not appreciated at the time, inevitably this led to the import and subsequent establishment of a wide range of non-indigenous terrestrial invertebrates and plants. Even today it remains virtually impossible to detect the majority of such introduction events as they occur. Thus it is not surprising that there is no documentation or study of these non-indigenous species and their impacts prior to the mid-twentieth century. It seems likely that many of the c. 200 non-indigenous species known to be established on the core sub-Antarctic islands (a figure itself likely to be a very conservative estimate of true numbers; Frenot et al. 2005) were introduced in this period rather than during the subsequent upsurge in research and tourism interest in the region since c. 1950 and 1980 respectively. However, Frenot et al. (2001) also document an increase in the rate of known introduction events after the establishment of research stations on the French sub-Antarctic islands in the 1950s and 1960 s. Gressitt (1970) reports the presence of the majority of non-indigenous species known today on South Georgia in studies carried out during the 1960s.

Small-scale cultivation of vegetable crops for domestic use in "garden" areas and greenhouses has also been a feature of communities on various sub-Antarctic islands, and subsequently on several Antarctic research stations, most of which were established after the period under consideration. This activity is again closely associated with the introduction and establishment of non-indigenous invertebrate and plant species (Greenslade 1987, 2006, Frenot et al. 2005, 2008, Convey et al. 2006b, de Villiers \& Cooper 2008). Deliberate historical introductions of trees are also known from some locations. For instance, vegetables and Pinus pinaster Alton were planted on Île Saint-Paul in 1857 but 
TABLE 2

Vertebrate species introduced to southern ocean islands in association with the early decades of human occupation

\begin{tabular}{ll}
\hline Island & $\begin{array}{l}\text { Vertebrate species accidentally or deliberarely introduced (including those commensal with } \\
\text { periods of human settlement but not established as feral populations) }\end{array}$ \\
\hline Islas Diego Ramírez & † Sheep (some individuals, brought for fresh food supply) \\
& No other introduced vertebrates \\
South Shetland Islands & $\ddagger$ Sledge Dogs - removed \\
South Orkney Islands & $\ddagger$ Sledge Dogs - removed \\
South Sandwich Islands & Free of introduced vertebrates \\
Bouvet Island & Free of introduced vertebrates \\
Sourh Georgia & Brown Rats (by 1820) - eradicated at certain sites \\
& Mice (1800s?) \\
& Reindeer (1910-1925) \\
& $\dagger$ Rabbics (c. 1880?) - died out \\
& $\dagger$ Sheep - removed (Mutton Island) \\
& $\ddagger$ Cats, Dogs, Poultry, Horses, Pigs
\end{tabular}

Tristan da Cunba group

Tristan da Cunha

Nightingale

Inaccessible

Gough Island

\section{Prince Edward Islands}

Marion Island

Prince Edward Island

Archipel Crozet

Île de La Possession

Île de l'Est

Île aux Cochons

Îlôts des Apôtres Île des Pingouins Îles Kerguelen
Black Rats (1882), Cats (1810), Dogs (1820), Cattle (1820), Donkeys (1860), Geese, Goats, Mice (1700s), Pigs, Sheep (1820)

i Sheep

$\uparrow$ Cattle, Pigs, Sheep

Mice (by 1888),

$\ddagger$ Cats (1919), Dogs $(1919,1957,1962)$, Poultry $(1956,1971)$

‡ Goats (1958-1959), Sheep (1956-1963)

Mice (1900s)

$\dagger$ Cats (1949) - eradicated in 1991

$\dagger$ Brown Trout Salmo trutta Linnaeus, 1758 —- died out

Free of introduced vertebrates

Black Rats (1850s?)

Brown Trout Salmo trutta (1969, 1972)

Brook Charr Salvenilus fontinalis Linnaeus, 1758 (1969)

$\neq$ Sheep, Pigs, Poultry

Rabbits (after 1826)

Mice (1800s?)

Cats (by 1887)

Rabbits (between 1837 and 1874)

$\dagger$ Pigs (c. 1820) -- died out

Free of introduced vertebrates

Free of introduced vertebrates

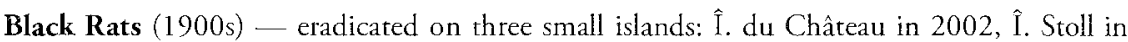
2003, Î. Australia in 2004

Cats (present in 1900s, then extinct, reincroduced in 1951 and 1956) - unsuccessful control program by shooting in 1960 and in the 1970s, eradicated on Île Guillou in 1994

Mice (by 1874)

Mouflon (1956,1957) - only present on Île Haute in 2008, eradication planned in 2009

Rabbits (1874) - unsuccessful attempt at control using myxomatosis virus in the 1950 s, successful eradicarion by poisoning on three small islands: I. Verte in 1992, $\hat{I}$. Guillou in 1994, $\hat{I}$. aux Cochons 1997

Reindeer (1955-56)

Sheep (1909-25, 1952) - only present on Île Longue in 2008

Brown Trout $(1958,1961,1979)$

Brook Charr (1961)

Arctic Charr Salvelinus alpinus (Linnaeus, 1758) (1990)

Atlantic Salmon Salmo salar Linnaeus, 1758 (1975-1980)

Coho Salmon Onchorhynchus kisutch Walbaum, 1792 (1978)

$\uparrow$ Rainbow trout O. mykiss (Walbaum, 1792) (1958)

† Chinook Salmon O. tshawytscha Walbaum, 1792 (1955)

† Lake Trout Salvelinus namaycush Walbaum, 1792 (1961)

$\dagger$ Mink Mustela vison (Schreber, 1777) (1956) - died out

$\uparrow$ Pigs (feral, 1900s)

¥ Horses, Pigs (in pigsty), Poultry 
Table 2 cont.

\begin{tabular}{|c|c|}
\hline Island & $\begin{array}{l}\text { Vertebrate species accidentally or deliberately introduced (including those commensal with } \\
\text { periods of human settlement but not established as feral populations) }\end{array}$ \\
\hline Île Amsterdam & $\begin{array}{l}\text { Brown Rats (1931) } \\
\text { Cats (1931) } \\
\text { Cattle (1871) - partially removed in 1988, eradication planned } \\
\text { Common Waxbill Estrilda astrild (Linnaeus, 1758) (1977) } \\
\text { Mice (1823) } \\
\dagger \text { Goats (1823) - removed c. } 1950 \\
\dagger \text { Kerguelen Pintail Anas eatoni eatoni (Sharpe 1875)(1954) - removed c. } 1970 \\
\dagger \text { Pigs (1799) - removed c. } 1873 \\
\dagger \text { Sheep (1871) - removed c. } 1954 \\
+ \text { Dogs, Pigs (in pigsty), Poultry }\end{array}$ \\
\hline Île Saint-Paul & $\begin{array}{l}\text { Mice }(1800 \text { s?) } \\
\dagger \text { Black Rats }(1700 \text { s?) - eradicated in } 1997 \\
\text { † Rabbits (after 1874) — eradicated in } 1997 \\
\text { † Cats (1877), Goats, Pigs }\end{array}$ \\
\hline Heard Island and McDonald Island & $\begin{array}{l}\text { Free of introduced vertebrates } \\
\pm \text { Atlas Cove Station: Dogs (1950), Sheep }(1952,1954)\end{array}$ \\
\hline Macquarie Island & $\begin{array}{l}\text { Black Rats (1900s) } \\
\text { Mice (1890s) } \\
\text { Rabbits (1878) - control programme commencing in 1978, eradication planned } \\
\text { Mallard Anas platyrhynchos Linnaeus, } 1758 \text { (arrived naturally, first record 1950s) } \\
\text { Red Poll Carduelis flammea (Linnaeus, 1758) (arrived naturally, first record 1912) } \\
\text { Starling Sturnus vulgaris Linnaeus, } 1758 \text { (arrived naturally, first record 1930) } \\
\dagger \text { Cats (by } 1820 \text { ) - eradicated in } 2000 \\
\dagger \text { Weka Gallirallus australis scotti (Ogilvie-Grant 1905) (1870s) - eradicated by } 1989 \\
\dagger \text { Sheep, Goats, Poultry, Horses, Dogs }\end{array}$ \\
\hline \multicolumn{2}{|l|}{ Auckland Islands group } \\
\hline Auckland Island & $\begin{array}{l}\text { Cats }(1820 \mathrm{~s}) \\
\text { Mice }(1820 \mathrm{~s}) \\
\text { Pigs }(1807) \\
\dagger \text { Goars }(1840 \mathrm{~s})-\text { eradicated in } 1989-91 \\
\dagger \text { Cattle }(1850 \mathrm{~s}), \text { Horses }(1850 \mathrm{~s}), \text { Dogs (1840s), Sheep (1840s) }\end{array}$ \\
\hline Enderby Island & $\begin{array}{l}\dagger \text { Cattle }(1849,1894) \text { - eradicated in } 1991-1993 \\
\dagger \text { Mice }(1849)-\text { eradicated in } 1993 \\
\dagger \text { Rabbits }(1840) \text { - eradicated in } 1993 \\
\ddagger \text { Goats }(1865) \text {, Sheep }(1849), \text { Dogs }(1842) \text {, Pigs (1842) }\end{array}$ \\
\hline Rose Island & $\begin{array}{l}\dagger \text { Rabbits (1849) - eradicated in } 1993 \\
\text { † Cattle (1894) and Sheep (1887) }\end{array}$ \\
\hline Ocean Island & † Goats (1890s) and Sheep (1940s) \\
\hline Adams Island & † Sheep and Goats (1890s) \\
\hline Ewing Island & $\dagger$ Goats $(1890)$ \\
\hline Snares Islands & Free of introduced vertebrates \\
\hline Campbell Island & $\begin{array}{l}\dagger \text { Brown Rats - eradicated in } 2001 \\
\text { † Cats - eradicated in } 2001 \\
\text { † Catde (1931) - eradicated in } 1984 \\
+ \text { Sheep (1895) - eradicated in } 1991\end{array}$ \\
\hline Antipodes Islands & $\begin{array}{l}\text { Mice } \\
\neq \text { Cattle (establishment attempt failed) }\end{array}$ \\
\hline Bounty Islands & Free of introduced vertebrates \\
\hline
\end{tabular}

In bold: species present in 2008 .

In brackets: date(s) of introduction or first record.

$\uparrow$ Died out or removed or eradicated.

$\$$ Present for a limited time in the past, usually associated with farming attempts or establishment of research stations, then died out or removed.

Scientific names for less frequent species are given in the table, otherwise see text.

I See also Taylor (1971), Davaine \& Beall (1982), Headland (1984), Chapuis et al. (1994), McIntosh \& Walton (2000), Chapuis et al. (2001), Copson \& Whinam (2001), Fell (2002), Torr (2002), Jones et al. (2003c), Frenot et al. (2005), Taylor (2006), de Villiers \& Cooper (2008), Terauds \& Stewart (2008). 
had disappeared by 1875 (Vélain 1877). More than 20 tree species were successfully planted on Île Amsterdam after the creation of its permanent research station in 1951 (Jolinon 1987, Frenot et al. 2001).

Inadvertent vertebrate introductions were also associated with many shipwrecks, in particular of rodents (House Mice, Mus musculus Linnaeus, 1758, Black Rats, Rattus rattus (Linnaeus, 1758), and Norway Rats (Brown Rats), $R$. norvegicus (Berkenhout, 1769)), a risk that occurs to the present day.

\section{CONSEQUENCES}

\section{Infrastructure}

The sealing, whaling and subsequent fishing industries exploited resources in the marine environment, causing drastic and possibly irreversible alterations to the Southern Ocean ecosystem (Trathan \& Reid 2009). The infrastructure requirements of the former two industries on land and at the coast were in some cases considerable and, likewise, would have had drastic impacts on local terrestrial ecosystems. Taking the whaling industry on South Georgia as an example, at its height in the early twentieth century, seven shore-based stations operated in different bays on the more sheltered northeast coast of the island (fig. 1). Although three of these were closed down quite rapidly (Prince Olav Harbour, Ocean Harbour, Godthul), the remaining four larger stations operated until the 1960s, and three derelict and unmaintained stations remain today (Husvik, Stromness, Leith) with only
Grytviken having been partially preserved (pl. 1a-c).

These stations were built and operated before the development of today's climate of environmental awareness, and thus were not subject to baseline environmental data collection, environmental impact assessment or ongoing monitoring of impacts. However, they were clearly major industrial sites, occupying a large proportion of the available valley floor areas, and would inevitably have led to the complete destruction of large areas of the preexisting terrestrial ecosystem within their coastal and valley locations, which would previously have provided the major contribution in terms of area of well-developed terrestrial ccosystems on the island. Construction and operation of the stations involved the import of all materials required for infrastructure, and would also have generated considerable levels of industrial pollution ( $\mathrm{pl} .1 \mathrm{~d}$ ), both from the station itself, and the large fleets of whale and seal catching vessels operating from them (indeed, some stations even had the capacity to construct and repair such vessels). After the stations were abandoned in the 1960 s, with no cleanup or removal of hazardous material, they were essentially left derelict and at the mercy of the prevailing weather. Under pressure from the increasing tourism industry, the station at Grytviken was partially preserved and made safe for visitors in the early 2000s (see also McIntosh \& Walton 2000), a process that served to highlight the quantities of hazardous material (e.g., asbestos, fuel oils, chemicals) still present on all the stations. At Grytviken, the assessment was made that, in the light of current international rules covering the transport of hazardous materials, some (in particular

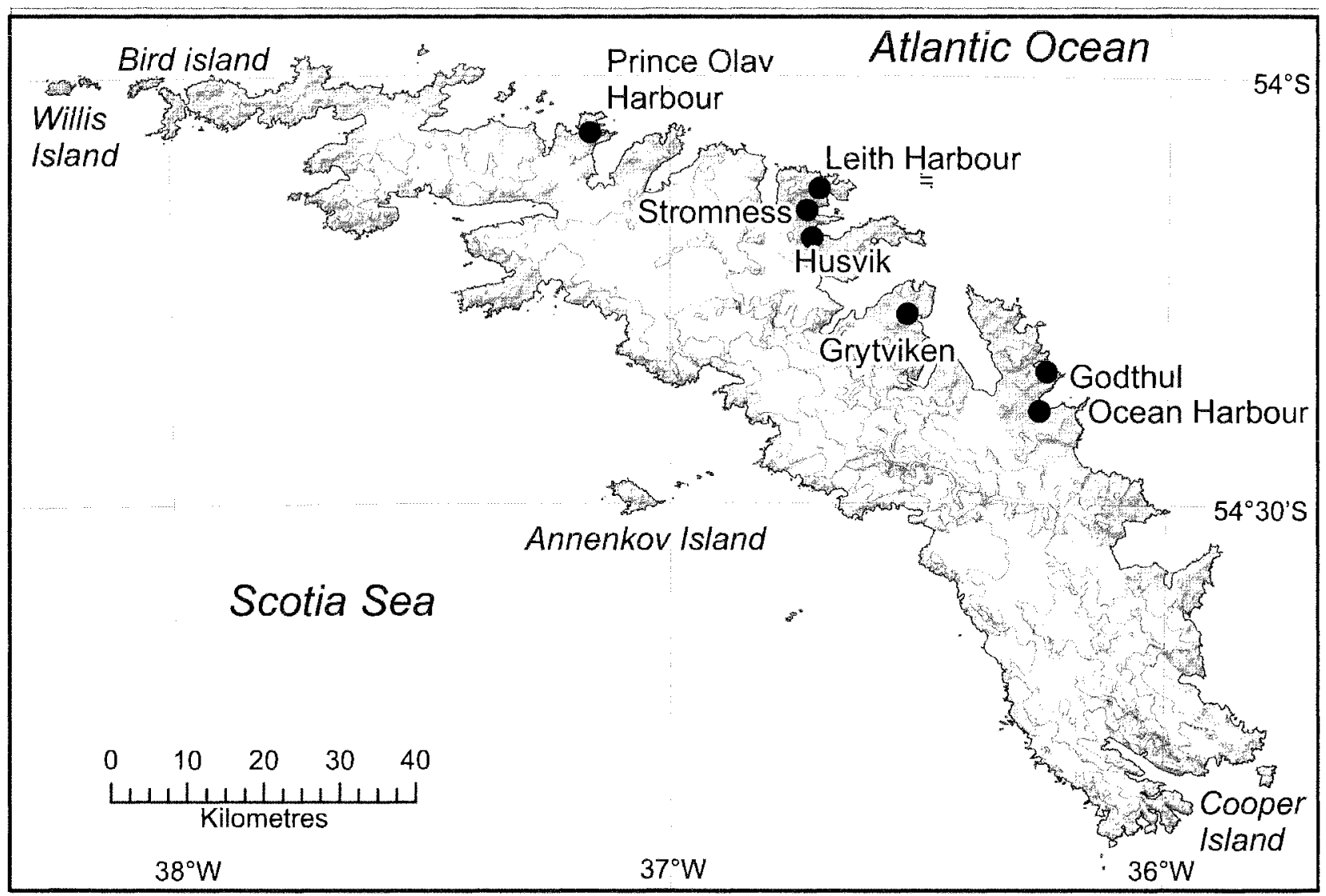

FIG 1. - Map of South Georgia indicating the seven locations at which shore-based whaling stations were constructed in the early twentieth century. 

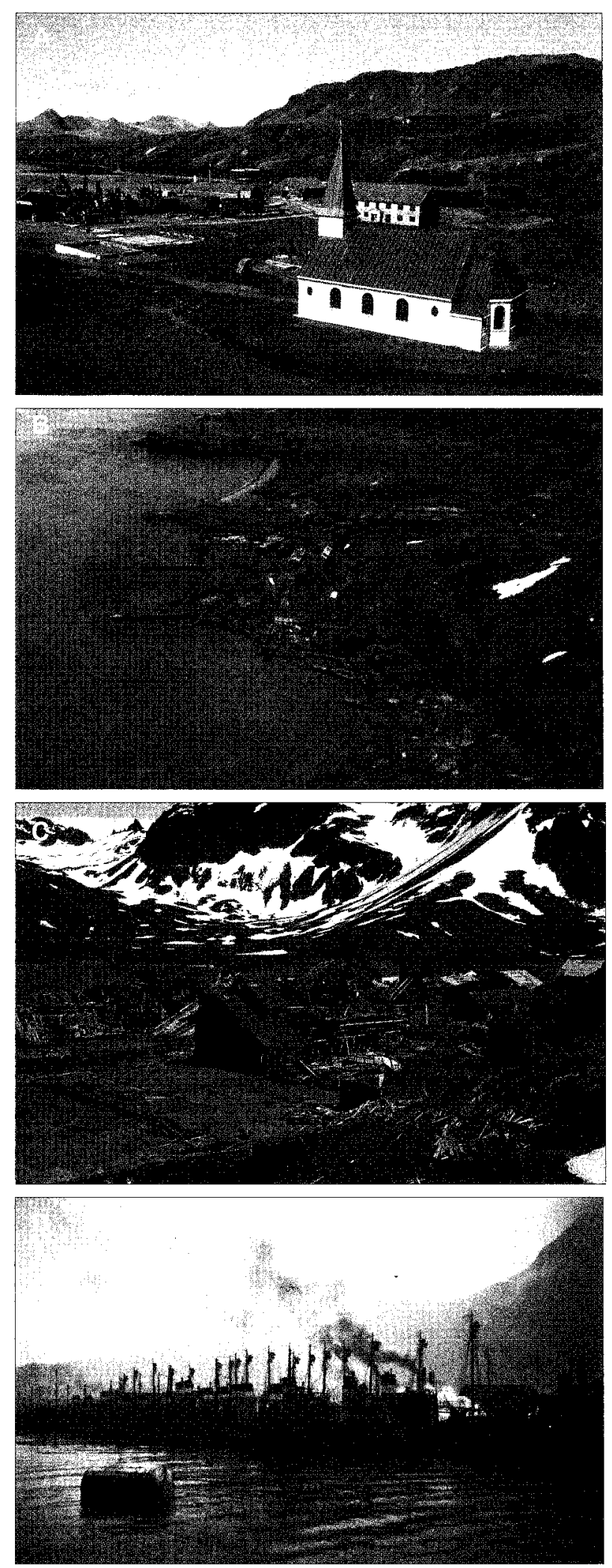

PLATE 1

South Georgia whaling stations: (A) view northeast over the recently partially-preserved Grytviken whaling station (Jan. 2006); (B) overview from north of the derelict Leith whaling station, illustrating the large proportion of the coastal low-lying ground directly impacted by its construction and operation (Dec. 1992); (C) derelict buildings and debris at Husvik whaling stations (Jan. 2006); (D) whaling vessels at a whaling station on South Georgia. (Photographs: A-C, P. Convey/BAS; D, N.A.G. Leppard, British Antarctic Survey Image Collection) that contaminated with asbestos) had to be buried on site. The remaining three larger stations have not been subject to cleanup and preservation, and are currently classified as unsafe and closed to visitors by the Government of South Georgia and the South Sandwich Islands, although they are not secured and debris continues to be dispersed into the local environment, and both marine mammals, birds and introduced vertebrates (Reindeer, Brown Rats) regularly pass through and even establish breeding colonies within the stations.

Human presence inevitably involves requirements for movement and transport, and a network of paths and larger tracks quickly developed within, around and between sites of industrial exploitation and, subsequently, scientific research stations, research sites and field huts. Today, these track networks are known to have twin impacts in terms of being both conduits for the dispersal of non-indigenous plant species (with propagules carried on, for example, footwear and clothing) (Whinam et al. 2005, Frenot et al. 2008), and by their direct damage to vegetation and compaction of soil along their lines (Gremmen et al. 2003, Tejedo et al. 2009, Tin et al. 2009).

\section{Transfer of marine biomass and nutrients to the land}

The major harvesting ind ustries of sealing and whaling would also have resulted in a considerable, but entirely unquantified, alteration of nutrient flows between the marine and terrestrial environments. The scale of harvesting involved was massive, including, for instance, the almost complete removal of the population of several million Antarctic Fur Seals, Arctocephalus gazella (Peters, 1875), from South Georgia, and the production of $c .100000$ barrels of oil from Southern Elephant Seals, on Heard Island. On South Georgia over 175000 whales were processed between 1904 and 1966 (Hart 2006), with a further 85000 being processed using factory ships and the shore station on Deception Island in the South Shetland Islands and Graham Land (northern Antarctic Peninsula, 19051931), c. 7000 in the South Orkney Islands (1911-1931) and c. 3000 in the South Sandwich Islands (1911/12 and 1927-1931) (Hart 2006). This level of harvesting resulted in the production of large quantities of unwanted carrion, which was simply dumped onshore or in the nearshore marine environment. The "waste" biomass associated with the onshore whale processing industry and factory ships located close to shore would probably have had the greatest impact locally, especially during the early years of the onshore processing industry when only the most valuable oil products were obtained - the density of whale bones on beaches of South Georgia bears witness to this. The transfer of marine biomass onto the land must have resulted in considerable fertilisation of coastal terrestrial habitats, while also providing a major food source for scavenging species of bird, and some native invertebrates, whose population dynamics would inevitably have been altered and that would also have distributed the nutrients more widely in the terrestrial environment.

The reduction in fur seal and Southern Elephant Seal numbers, and also penguins at locations where they were exploited for oil or as fuel for the processing of whale and seal oil, may have partially countered this effect on a local scale, through a reduction in manuring or guano input to terrestrial ecosystems. However, this reduction would also have resulted in much reduced levels of trampling of terrestrial habitats by these seals, which may paradoxically 
have permitted expansion of the tussock grass and megaherb vegetation now regarded as typical of many sub-Antarctic islands into coastal regions in the vicinity of their breeding and haul-out locations. In the maritime Antarctic, recent expansions in Antarctic Fur Seal numbers and range (including to locations where they have not been present at least since Pleistocene glacial retreat) are documented to have resulted in considerable destruction of fragile terrestrial vegetation in the South Orkney and South Shetland islands (Smith 1988, Hodgson \& Johnston 1997, Hodgson et al. 1998), a process now extending to locations along the Antarctic Peninsula. These expansions are thought to be directly linked with recovery of the source populations in the western part of South Georgia, which are at levels at least comparable with and possibly greater than those that existed pre-exploitation (Boyd 1993, Boyd et al. 1996). However, no comparable studies of their impacts on South Georgia (or other sub-Antarctic island) vegetation have been published, although populations of both Antarctic and sub-Antarctic (Arctocephalus tropicalis (J.E. Gray, 1872)) Fur Seals are recovering and subjective observation would indicate that maintenance of the "typical" vegetation is not compatible in the vicinity of the recovered Fur Seal populations (pl. 2).
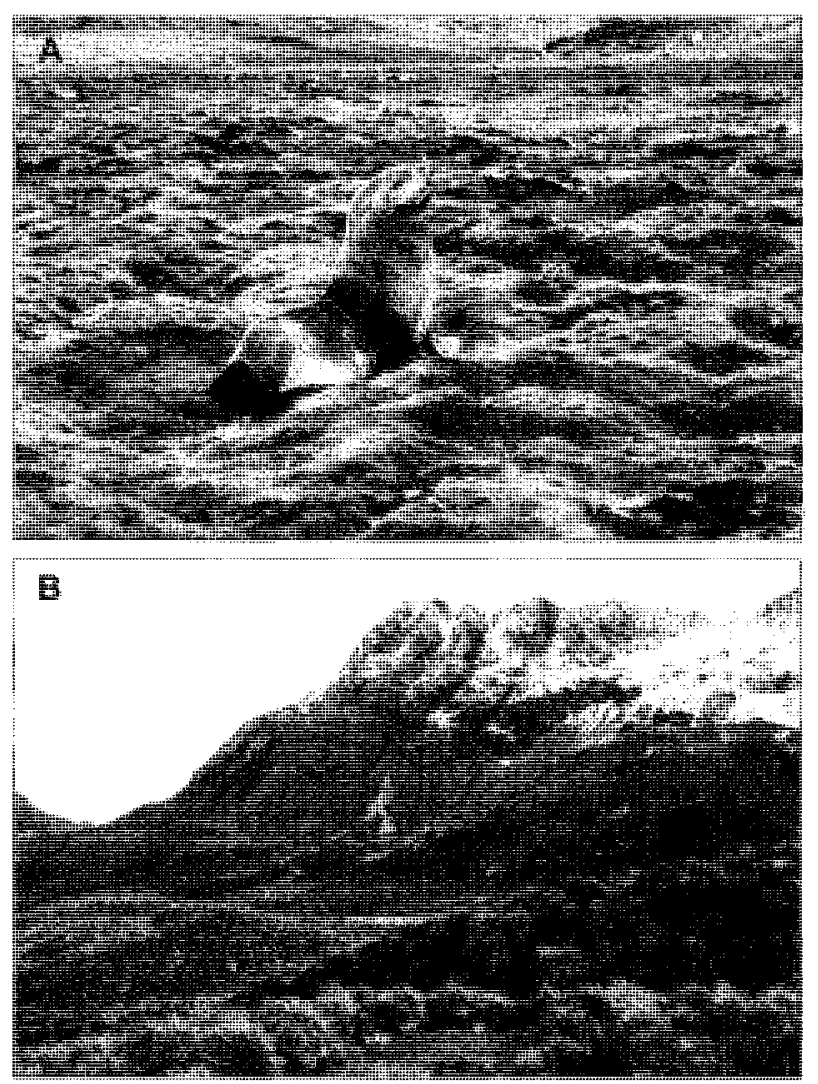

PLATE 2

The impact of fur seal trampling on typical sub-Antarctic terrestrial vegetation - a comparison of $(A)$ heavily impacted vegetation where tussock grass has been displaced and the dead tussock stools colonised by the moss Polytrichum strictum Brid. (Moltke Harbour, South Georgia) (Jan. 2006), and (B) non-impacted tussock grass vegetation from Cooper Bay, South Georgia (Jan. 2006) (photographs: P. Convey).

\section{Impacts of introduced mammals and birds}

The indigenous terrestrial faunas of the sub-Antarctic islands do not include mammalian herbivores or predators. Nonmarine birds are limited on the core sub-Antarctic islands to a single (endemic to South Georgia) species of passerine, two ducks and two sheathbills. The New Zealand shelf islands host greater bird diversity. The anthropogenic introduction of vertebrate herbivores and predators to most sub-Antarctic islands has inevitably led to considerable deleterious impacts on indigenous ecosystems (Bonner 1984, Leader-Williams 1988, Chapuis et al. 1994, Bester et al. 2002, Frenot et al. 2005, 2008, Convey et al. 2006b), in some examples leading to the virtually complete destruction of native ecosystems (e.g., Chapuis et al. 1994, Bergstrom et al. 2009). On Île Amsterdam, grazing and trampling by feral cattle (introduced in 1871) and several fires, accidentally caused by human activity, have contributed to drastic ecosystem changes in lowaltitude areas, including soil erosion, and dramatic decreases in native plant cover, most visibly that of the native tree Phylica arborea Thouars (Frenot \& Valleix 1990). According to early visitors, this tree formed a continuous belt along the east coast of Île Amsterdam, between 100 and 150 metres a.s.I. By 1874 only nine small patches of trees remained (Vélain 1877), and in 1988 most of the remnants were located in a single small wood. As part of a restoration program (Micol $\&$ Jouventin 1995) a fence was erected across the island in 1988 , cattle were eradicated from the southern part, and 8000 individuals of P. arborea were subsequently planted (fig. 2). On Enderby Island and to a lesser extent on Rose Island the vegetation present in the 1950s (Taylor 1971) had been heavily modified by fire and introduced mammals, the latter subsequently being eradicated (Torr 2002).

In concert with the loss of native vegetation, grazing mammals have facilitated the spread of non-indigenous plant species, such as the grass Poa annua L., which in turn impacts the foraging dynamics of invertebrate communities (Chown \& Block 1997). Several other plant species introduced in this era have now been identified as being "aggressive invasives", capable of occupying new locations and displacing native species, and further "persistent invasive" species are predicted to change status as a consequence of contemporary climate change trends (Frenot et al. 2005). Introduced vertebrate predators (cats, rats, mice) have had drastic impacts on breeding bird populations on all islands to which they have been introduced, primarily through nest predation, leading to much reduced breeding diversity when adjacent islands with and without predators are compared (e.g., Anonymous 1996). A comparison berween two similar islands, $20 \mathrm{~km}$ apart, in Archipel Crozet highlights the dramatic impact of rats on bird communities. Eight petrel species are present today on Île de la Possession, where rats were introduced in the nineteenth century, contrasting with 17 species on Île de l'Est which is free of rats (Jouventin et al. 1984). The size of the bird populations on adjacent small islands (around $150 \mathrm{ha}$ ) in the Golfe du Morbihan (Îles Kerguelen) has been estimated to be tens to hundreds of thousands of pairs in the absence of cats as against only 100 pairs in their presence (Chapuis et al. 2001). Rats and mice have wideranging impacts on vertebrate, invertebrate and vegetation elements of terrestrial ecosystems (e.g., Pye \& Bonner 1980; Chown \& Smith 1993, Le Roux et al. 2002, Jones et al. 2003a, Shaw et al. 2005, Phiri et al. 2009). 
Non-indigenous invertebrates can also have important impacts on sub-Antarctic ecosystems. The predatory carabid beetles, Trechisibus antarcticus (Dejean, 1831) and Merizodus soledadinus (= Oopterus soledadinus) (Guérin-Méneville, 1832), are both spreading in their introduction areas on South Georgia (both species) and Îles Kerguelen ( $M$. soledadinus), and having direct and indirect effects on their native and often endemic invertebrate prey species (Ernsting 1993, Ensting et al. 1995, 1999, Chevrier et al. 1997, Frenot et al. 2008; see also Jones et al. 2003b). The spread of the non-indigenous flesh fy Calliphora vicina RobineauDesvoidy, 1830 on Illes Kerguelen has been linked with reduced abundance of an indigenous dipteran competitor, Anatalanta aptera Eaton, 1875 (Chevrier et al. 1997). The detritivorous larvae of the introduced midge Limnophyes minimus Meigen, 1818 may contribute substantially to nutrient turnover on Marion Island, possibly comparable to that of the indigenous tineid moth Pringleophaga marioni Viette, 1968 (Hänel \& Chown 1998). Slabber \& Chown (2002) suggested that, if the introduced woodlouse Porcellio scaber Latreille, 1804 were to spread on Marion Island, it would substantially alter nutrient cycling by reducing the bottleneck currently imposed by lepidopteran larvae and earthworms. On Île Amsterdam phytophagous mammals do not form part of the native fauna and, in the absence of a typical coprophagous invertebrate fauna, the very numerous inrroduced woodlice play a major role in cattle dung degradation (Tréhen et al. 1990).

\section{CONCLUDING DISCUSSION}

It is clear from the foregoing that human activity has had considerable impacts on the terrestrial ecosystems of virtually all the sub-Antarctic islands. While primarily associated with the marine exploitation industries of sealing and whaling, the development and operation of industrial infrastructure and the transfer of large quantities of marine biomass and nutrients into the terrestrial environment will inevitably have had large but unquantified impacts on terrestrial ecosystems. The deliberate and accidental release of grazing and predatory vertebrates on most islands, as part of attempted farming operations or in support of shipwreck survivors, led to perhaps the greatest structural changes within these ecosystems and was accompanied by many inadvertent introductions of invertebrates and plants.

It is only in recent decades that the impacts of these various introductions on sub-Antarctic terrestrial ecosystem structure and function have started to be appreciated, and have become a serious cause for concern in the context of the conservation of these ecosystems and their biodiversity. Throughout the era between the islands' initial discovery and exploitation and the mid-twentieth century, ecological research and conservation were not issues of priority, and thus studies or documentation of human impacts, terrestrial ecosystems or non-indigenous species, or baseline biodiversity monitoring programs, simply do not exist. Thus, as illustrated by the discussion above relating to impacts of

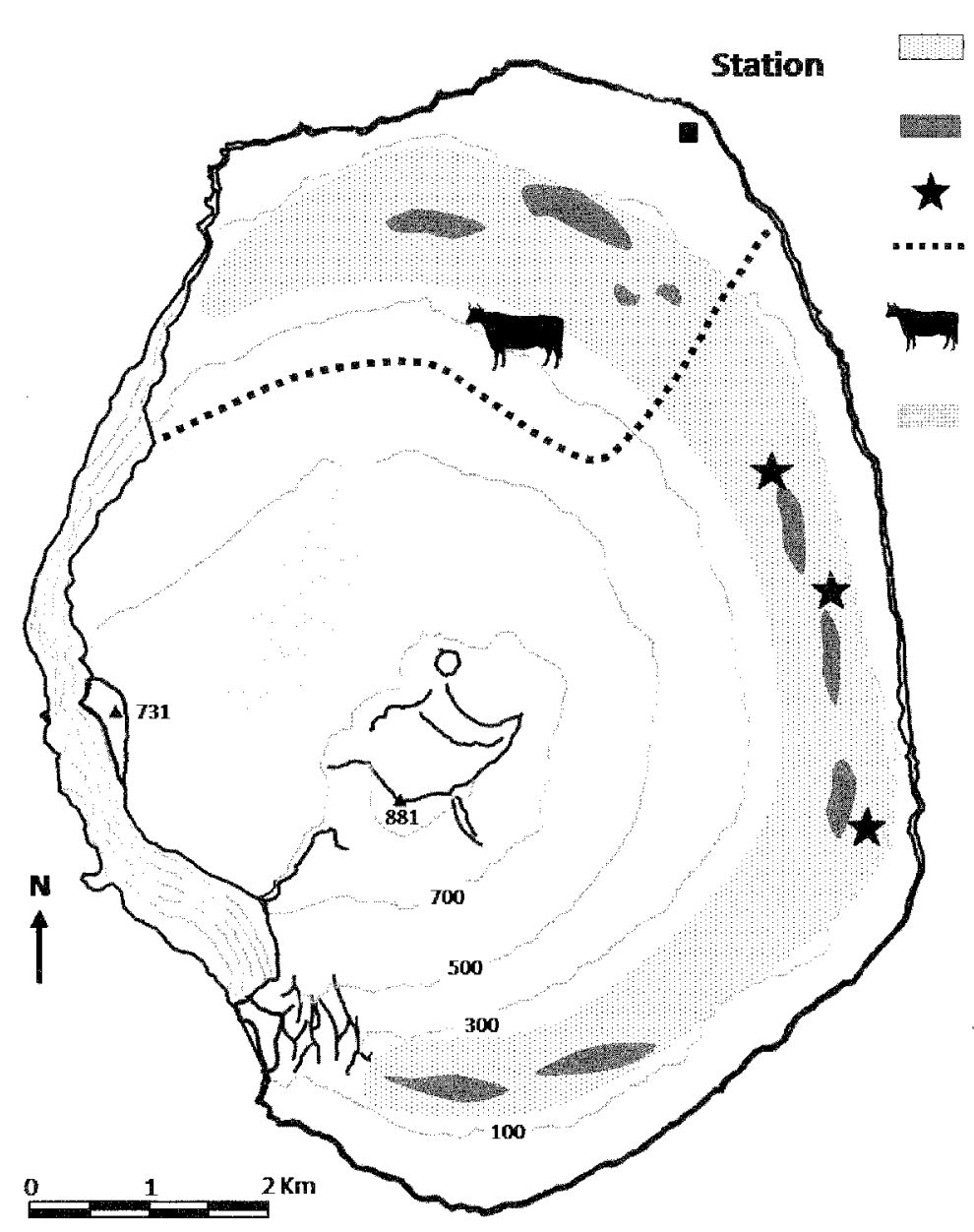

Hypothetical extent of Phylica arborea according to reports of early visitors during the 17 th and 18 th centuries Approximative location of groves of Phylica arborea reported by Vélain in 1874

Main groves of Phylica arborea in 1988 Fence

Cattle were shot south of the fence in 1988-89 and a small heard was left in the northem part of the island

Breeding area of the Amsterdam albatross

FIG. 2 - The impact of feral cattle and accidental fires caused by human activity on the extent of native trees on Ile Amsterdam. A fence was erected across the island in 1988 and cattle were removed from the larger part of the island in order to protect the trees, the peat bogs and the breeding area of an endemic albatross. 
fur seal exploitation and subsequent population recovery, some caution is required when attempting to identify the baseline (i.e., non-impacted) structure and distribution of sub-Antarctic terrestrial ecosystems - something that is an integral element of any attempt to identify potential consequences and indicators of contemporary environmental change. Conversely, there are also examples where the presence of non-indigenous species itself provides a valuable opportunity that would not otherwise be available to the research community. For instance, in certain archipelagos (e.g., Îles Kerguelen) the existence of reference and control islands (e.g. with or without introduced mammals) offers opportunities both to understand their direct impacts, and also to distinguish the effects of management intervention (e.g., eradication) from those of other factors (e.g., climate change) (Chapuis et al. 2002, 2004). Likewise, the impacts of introducing a new trophic function to an ecosystem (as with the example of predatory carabid beetles) can be explored by comparing adjacent impacted and non-impacted communities, providing an opportunity for field research to address fundamental questions of ecological theory.

Many of the impacts identified above as commencing during the era of human exploitation of sub-Antarctic resources continue to the present day. Thus, while some eradication programs have been completed (e.g., Chapuis et al. 2001, Bester et al. 2002), generally targeting specific introduced predators (cats, rats) as these are perceived to present the greatest threat at least to charismatic indigenous vertebrate populations, the consequences of these have not always been as straightforward or effective as hoped (see Courchamp et al. 2003, Chapuis et al. 2004, Frenot et al. 2005, Bergstrom et al. 2009). The large majority of non-indigenous vertebrates remain uncontrolled on most islands, with objective evidence now accumulating rapidly of their deleterious consequences for terrestrial ecosystems. No attempt has been made, or in most cases would be practicable, to eradicate any known non-indigenous invertebrates or plants introduced with human assistance (with some exceptions, e.g., Sagina procumbens (Linnaeus) on Gough Island (Gremmen et al. 2002), Stellaria media and P. annua on Snares Islands (Torr 2002)), while it is likely that many further examples remain to be recognised. Management plans and procedures developed for certain islands (e.g., Anonymous 1994, 1996, McIntosh \& Walton 2000, Davies et al. 2007, Roberts 2007) now recognise the need to minimise the risk of new introduction events, and specify various measures to assist in achieving this end (see also Whinam 2009).

Exploitation of the resources of the Southern Ocean marine environment continues today in the form of various fisheries (fish, squid, krill, spider crabs) (Trathan \& Reid 2009). Other than through seabird bycatch, one of whose associated impacts will be a reduction in transfer of marinederived nutrients to the terrestrial environment. These do not involve the level of contact with the land as did the sealing and whaling industries. The primary risk is now that of shipwreck, as has occurred on several occasions in recent years, and particularly the risk of rodents thereby being introduced to areas that are currently rodent-free. Rather, the prime areas of interaction between humans and the sub-Antarctic terrestrial environment today take the forms of governmental scientific research activities and ecotourism. Together, these bring tens of thousands of individuals into the region each year, and considerable attention is now being given to identifying and minimising the risks associated with these activities to the sub-Antarctic and Antarctic environments (Frenot et al. 2005, 2008, Convey 2008, Tin et al. 2009, Whinam 2009).

\section{ACKNOWLEDGEMENTS}

We thank the meeting organisers for the invitation and support to present at the Second International Forum on the sub-Antarctic, and Dana Bergstrom, Herbert Dartnall and Patricia Selkirk for helpful and constructive comments on an earlier version. This paper forms an output of the BAS "Ecosystems" and SCAR "Evolution and Biodiversity in Antarctica" research programs. ML is grateful for the research resources of the French Polar Institute (Programme 136) and the CNRS (Zone Atelier de Recherches sur l'Environnement Antarctique et Subantarctique).

\section{REFERENCES}

Allen, M.F. 1997: Wake of the Invercauld. Exisle Publishing Ltd., Auckland: $256 \mathrm{pp}$.

Anderson, A.J. 2006: The first human inhabitants of the Auckland Islands in a South Polynesian perspective. In Auckland Islands 1806-2006. A record of events celebrating the bicentennial of European discovery. 18-19 August 2006, Wellington, New Zealand. Published on CD by the Royal Society of New Zealand, Wellington.

Anderson, A.J. 2009: Prehistoric archaeology in the Auckland Islands, New Zealand subantarctic region. In Dingwell, P.R., Jones, K.L. \& Egerton, R. (eds): In Care of the Southern Ocean. Archaeological and Historical Survey of the Auckland Islands. New Zealand Archaeological Association Monograph 27: 9-37.

Anonymous 1994: Heard Island Wilderness Reserve. Management Plan. Australian Antarctic Division, Hobart: 67 pp.

Anonymous 1996: Prince Edward Islands Management Plan. Department of Environmental Affairs and Tourism, Pretoria: $64 \mathrm{pp}$.

Basberg, B.L. 2004: The Shore Whaling Stations at South Georgia. Christensen's Whaling Museum, Sandefford: $226 \mathrm{pp}$.

Bergstrom, D.M., Lucieer, A., Kiefer, K., Wasley, J., Belbin, L., Pedersen, T.K. \& Chown, S.L. 2009: Indirect effects of invasive species removal devastate World Heritage Island. Journal of Applied Ecology 46: 73-81.

Bergstrom, D.M. \& Selkirk, P.M. 2007: Human impacts on subAntarctic cerrestrial environments. Papers and Proceedings of the Royal Society of Tasmania 141(1): 159-168.

Bester, M.N., Bloomer, J.P., Van Aarde, R.J., Erasmus, B.H., Van Rensburg, P.J.J., Skinner, J.D., Howell, P.G. \& Naude, T.W. 2002: A review of the successful eradication of feral cats from sub-Antarctic Marion Island, Southern Indian Ocean. South African Journal of Wildlife Research 32: 65-73.

Bonner, W.N. 1984: Introduced mammals. In Laws, R.M. (ed.): Antarctic Ecology, Volume 1, Academic Press, London: 237-278.

Boyd, I.L. 1993: Pup production and distribution of breeding Antarctic fur seals (Arctocephalus gazella) at South Georgia. Antarctic Science 5: 17-24.

Boyd I.L., Walker, T.R. \& Poncet, J. 1996: Status of southern elephant seals at South Georgia. Antarctic Science 8: 237-244.

Chapuis, J.L., Boussès, P. \& Barnaud, G. 1994: Alien mammals, impact and management in the French subantarctic islands. Biological Conservation 67: 97-104.

Chapuis, J.L., Frenot, Y. \& Lebouvier, M. 2002: Une gamme d'îles de référence, un atout majeur pour l'évaluation de 
programmes de restauration dans l'archipel de Kerguelen. Revue d'Ecologie (Terre et Vie) Suppl. 9: 121-130.

Chapuis, J.L., Frenot, Y. \& Lebouvier, M. 2004: Recovery of native plant communities after eradication of rabbits from the subantarctic Kerguelen Islands, and influence of climate change. Biological Conservation 117: 167-179.

Chapuis, J.L., Le Roux, V., Asseline, J., Lefevre, L. \& Kerleau, F. 2001: Eradication of the rabbit (Oryctolagus cuniculus) by poisoning, on three islands of the subantarctic Archipelago of Kerguelen. Wildilife research 28: 323-331.

Chevrier, M., Vernon, P. \& Frenot, Y. 1997: Potential effects of two alien insects on a subantarctic wingless fly in the Kerguelen Islands. In Battaglia, B., Valencia, J. \& Walton, D.W.H. (eds): Antarctic Communities: Species, Structure and Survival. Cambridge University Press, Cambridge: $424-431$.

Chown, S.L. \& Block, W. 1997: Comparative nutritional ecology of grass-feeding in a subantarctic beetle: the impact of introduced species on Hydromedion sparsutum from South Georgia. Oecologia 111: 216-224.

Chown, S.L. \& Smith, V.R. 1993: Climate change and the shortterm impact of feral house mice at the sub-Antarctic Prince Edward Islands. Oecologia 96: 508-516.

Convey, P. 1996: Overwintering strategies of terrestrial invertebrates from Antarctica - the significance of flexibility in extremely seasonal environments. European Journal of Entomology 93: 489-505.

Convey, P. 2007a: Influences on and origins of terrestrial biodiversity of the sub-Antarctic islands. Papers and Proceedings of the Royal Society of Tasmania 141(1): 83-93.

Convey, P. 2007b: Antarctic Ecosystems. In Levin, S.A. (ed.): Encyclopedia of Biodiversity, 2nd (online) edn. Elsevier, San Diego: doi:10.1016/B0-12-226865-2/00014-6.

Convey, P. 2008: Non-native species in Antarctic terrestrial and freshwater environments: presence, sources, impacts and predictions. In Rogan-Finnemore, M. (ed.): Non-native Species in the Antarctic Proceedings. Gateway Antarctica, Christchurch: 97-130.

Convey. P., Chown, S.L., Wasley, J. \& Bergstrom, D.M. 2006a: Life history traits. In Bergstrom, D.M., Convey, P. \& Huiskes, A.H.L. (eds): Trends in Antartic Terrestrial and Limnetic Ecosystems: Antarctica as a Global Indicator. Springer, Dordrecht: 101-127.

Convey, P., Frenot, F., Gremmen, N. \& Bergstrom, D. 2006b: Biological invasions. In Bergstrom, D.M, Convey, P. \& Huiskes, A.H.L. (eds): Trends in Antarctic Terrestrial and Limnetic Ecosystems: Antarctica as a Global Indicator. Springer, Dordrecht: 193-220.

Cook, A.J., Poncet, S., Cooper, A.P.R., Herbert, D.J. \& Christie, D. Glacier retreat and the tisk of rat spread on South Georgia. Unpublished.

Cooper, J. 2008: Human history. In Chown, S.L. \& Froneman, P.W. (eds): The Prince Edward Islands: land-sea interactions in a changing ecosystem. Sun Press, Stellenbosch: 331-350.

Courchamp, F., Chapuis, J.L. \& Pascal, M. 2003: Mammal invaders on islands: impact, control and control impact. Biological Review 78: 347-383.

Cumpston, J.S. 1968: Macquarie Island. Antarctic Division, Melbourne: $380 \mathrm{pp}$.

Davaine, P. \& Beall, E. 1982: Introductions de salmonidés dans les Terres Australes et Antarctiques Françaises. Comité National Français des Recherches Antarctiques 51: 289-300.

Davies, S.J., Chown, S.L. \& Joubert, L.S. 2007: Renewed management system and provisions for South Africa's sub-Antarctic islands. Papers and Proceedings of the Royal Society of Tasmania 141(1): 115-120.

De Villiers, M.S. \& Cooper, J. 2008: Conservation and management. In Chown, S.L. \& Froneman, P.W. (eds): The Prince Edward Islands: Land-sea Interactions in a Changing Ecosystem. Sun Press, Stellenbosch: 301-330.

Dingwall, P. 2007: Auckland Islands. In Riffenburgh, B. (ed.):
Encyclopedia of the Antarctic, Volume 1. Routledge, New York: 104-105.

Ernsting, G. 1993: Observations on life cycle and feeding ecology of two recently introduced predatory beetle species at South-Georgia, sub-Antarctic. Polar Biology 13: 423-428.

Ernsting, G., Block, W., MacAlister, H. \& Todd, C. 1995: The invasion of the carnivorous carabid beetle Trechisibus antarcticus on South Georgia (subantarctic) and its effect on the endemic herbivorous beetle Hydromedion sparsutum. Oecologia 103: 34-42

Ernsting, G., Brandjes, G.J., Block, W. \& Isaaks, J.A. 1999: Life-history consequences of predation for a subantarctic beetle: evaluating the contribution of direct and indirect effects. Journal of Animal Ecology 68: 741-752.

Fell, D. 2002: Campbell Island: Land of the Bhue Sunflower. David Bateman Lid, Auckland: $143 \mathrm{pp}$.

Fraser, C. 1986: Beyond the Roaring Forties - New Zealand's SubAntarctic Islands. Government Printer, Wellington: $214 \mathrm{pp}$.

Frenot, Y., Chown, S.L., Whinam, J., Selkirk, P., Convey, P., Skotnicki, M. \& Bergstrom, D. 2005: Biological invasions in the Antarctic: extent, impacts and implications. Biological Reviews 80: 45-72.

Frenot, Y., Convey, P., Lebouvier, M., Chown, S.L., Whinam, J., Selkirk, P.M., Skotnicki, M. \& Bergstrom, D.M. 2008: Antarctic biological invasions: sources, extents, impacts and implications. In Rogan-Finnemore, M. (ed.): Non-native Species in the Antarctic Proceedings. Gateway Antarctica, Christchurch: 53-96.

Frenot, Y., Gloaguen, J.C., Massé, L. \& Lebouvier, M. 2001. Human activities, ecosystem disturbance and plant invasions in subantarctic Crozet, Kerguelen and Amsterdam Islands. Biological Conservation 101: 33-50.

Frenot, Y. \& Valleix, T. 1990: Carte des sols de l'Ile Amsterdam (Terres Australes et Antarctiques Françaises). Comité National Frangais des Recherches Antarctiques 59: 1-48.

Greenslade, P. 1987: Invertebrate conservation in the Antarctic and subantarctic. In Majer, J.D. (ed.): The Role of Invertebrates in Conservation and Biological Survey. Western Australian Department of Conservation \& Land Management, Perth: 119-121.

Greenslade, P. 2006: The Invertebrates of Macquarie Island. Australian Antarctic Division, Kingston, Tasmania, xvi, $326 \mathrm{pp}$.

Gremmen, N.J.M., Barendse J. \& Orr, I. 2002: Invasion and eradication of Sagina procumbens L. (Procumbent pearlwort) on Gough Island. Aliens 14: 19-20.

Gremmen, N.J.M., Smith, V.R. \& van Tongeren, O.F.R. 2003: Impact of trampling on the vegetation of subantarctic Marion Island. Arctic, Antarctic, and Alpine Research 35: $442-446$.

Gressitt, J.L. 1970: Subantarctic entomology and biogeography. Pacific Insects Monograph 23: 295-374.

Hänel, C. \& Chown, S.L. 1998: The impact of a small, alien macro-invertebrate on a sub-Antarctic terrestrial ecosystem: Limnophyes minimus Meigen (Diptera, Chironomidae) at Marion Island. Polar Biology 20: 99-106.

Hart, I.B. 2006: Whaling in the Falkland Islands Dependencies, 1904-1931. Pequena, Newton St. Margarets: 363 pp

Headland, R.K. 1984: The Island of South Georgia. Cambridge University Press, Cambridge: 293 pp.

Hodgson, D.A. \& Johnston, N.M. 1997: Inferring seal populations from lake sediments. Nature 387: 30-31.

Hodgson, D.A., Johnston, N.M., Caulkett, A.P. \& Jones, V.J. 1998: Palaeolimnology of Antarctic fur seal Arctocephalus gazella populations and implications for Antarctic management. Biological Conservation 83: 145-154.

Jolinon, J.C. 1987: Les phanérogames adventices sur l'lle Amsterdam. Comité National Français des Recherches Antarctiques 58: 133-188.

Jones, A.G., Chown, S.L. \& Gaston, K.J. 2003a: Introduced house mice as a conservation concern on Gough Island. 
Biodiversity and Conservation 12: 2107-2119.

Jones, A.G., Chown, S.L., Ryan, P.G., Gremmen, N.J.M. \& Gaston, K.J. 2003c: A review of conservation threats on Gough Island: a case study for tertestrial conservation in the Southern Oceans. Biological Conservation 113:75-87.

Jones, A.G., Chown, S.L., Webb, T.J. \& Gaston, K.J. 2003b: The free-living pterygote insects of Gough Island, South Atlantic Ocean. Systematics and Bioidiversity 1: 213-273.

Jouventin, P., Stahl, J.C., Weimerskirch, H. \& Mougin, J.L. 1984: The seabirds of the French subantarctic islands and Adelie land, their status and conservation. In Croxall, J.P, Evans, P.G.H. \& Schreiber, R.W. (eds): Status and Conservation of the World's Seabirds. International Council for Bird Preservation, Cambridge: 609-625.

Leader-Williams, N. 1988: Reindeer on South Georgia: The Ecology of an Introduced Population. Cambridge University Press, Cambridge: 319 pp.

Lebouvier, M. \& Frenot, Y. 2007: Conservation and management in the French sub-Antarctic islands and surrounding seas. Papers and Proceedings of the Royal Society of Tasmania 141(1): 23-28.

le Roux, P.C. 2008: Climate and climate change. In Chown, S.L. \& Froneman, P.W. (eds): The Prince Edward Islands: Land-sea Interactions in a Changing Ecosystem. Sun Press, Stellenbosch: 39-64.

Le Roux, V., Chapuis, J.L., Frenot, Y. \& Vernon, P. 2002: Diet of the house mouse (Mus musculus) on Guillou Island, Kerguelen archipelago, Subantarctic. Polar Biology 25: 49-57.

McIntosh, E. \& Walton, D.W.H. 2000: Environmental Management Plan for South Georgia. Government of South Georgia and South Sandwich Islands, Cambridge: 105 pp.

Meurk, C.D., Foggo, M.N. \& Wilson, J.B. 1994: The vegetation of subantarctic Campbell Island. New Zealand Journal of Ecology 18: 123-168.

Micol, T. \& Jouventin, P. 1995: Restoration of Amsterdam Island, South Indian Ocean, following control of feral cattlc. Biological Conservation 73: 199-206.

Mitchell, A.D., Meurk, C.D. \&Wagstaff, S.J. 1999: Evolution of Stilbocarpa, a megaherb from New Zealand's sub-antarctic islands. New Zealand Joumal of Botany 37: 205-211.

Pendlebury, S.F. \& Barnes-Keoghan, I.P. 2007: Climate and climate change in the sub-Antarctic. Papers and Proceedings of the Royal Society of Tasmania 141(1): 67-81.

Phiri, E.E., Mcgeoch, M.A. \& Chown, S.L. 2009: Spatial variation in structural damage to a keystone plant species in the sub-Antarctic: interactions between Azorella selago and invasive house mice. Antarctic Science 21: 189-196.

Pye, T. \& Bonner, W.N. 1980: Feral brown rats, Rattus norvegicus, in South Georgia (South Atlantic Ocean). Journal of Zoology 192: 237-255.

Roberts, A.D. 2007: Management framcworks for the New Zealand sub-Antarctic islands. Papers and Proceedings of the Royal Society of Tasmania 141(1): 29-32.

Russ, R. 2007. History, exploration, settlement and past use of the sub-Antarctic. Papers and Proceedings of the Royal Society of Tasmania 141(1): 169-72.

Selkirk, P.M. 2007. The nature and importance of the subAntarctic. Papers and Proceedings of the Royal Society of Tasmania 141(1): 1-6.

Shaw, J.D, Bergstrom, D.M \& Hovenden, M. 2005: The impact of feral rats (Rattus rattus) on populations of subantarctic megaherb (Pleurophyllum hookeri). Austral Ecology 30: $118-125$.

Slabber, S. \& Chown, S.L. 2002: The first record of a terrestrial crustacean, Porcellio scaber (Isopoda, Porcellionidae), from sub-Antarctic Marion Island. Polar Biology 25: 855-858.
Smith, R.I.L. 1984: Terrestrial plant biology of the sub-Antarctic and Antarcic. In Laws, R.M. (ed.): Antarctic Ecology, Volume 1. Academic Press, London: 61-162.

Smith, R.I.L. 1988: Destruction of Antarctic terrestrial ecosystems by a rapidly increasing fur seal population. Biological Conservation 45: 55-72.

Taylor, R. 2006: Straight Through from London: The Antipodes and Bounty Islands, New Zealand. Heritage Expeditions, Christchurch: $415 \mathrm{pp}$

Taylor, R.H. 1971: Influcnce of man on vegetation and wildlife of Enderby and Rose Islands, Auckland Islands. New Zealand Journal of Botany 9: 225-268.

Tejedo, P., Justel, A., Benays, J., Rico, E., Convey, P. \& Quesada, A. 2009: Soil trampling in an Antarctic Specially Protected Area: tools to assess levels of human impact. Antarctic Science 21: 229-236.

Terauds, A. \& Stewart, F. 2008: Subantarctic Wilderness: Macquarie Island. Allen \& Unwin, Crows Nest, NSW: 176 pp.

Tin, T., Fleming, Z., Hughes, K.A., Ainley, D., Convey, P., Moreno, C., Pfeiffer, S., Scott, J. \& Snape, I. 2009: Impacts of local human activities on the Antarctic environment: a review. Antarctic Science 21: 3-33.

Torr, N. 2002: Eradication of rabbits and mice from subantarctic Enderby and Rose Islands. In Veitch, C.R. \& Clout, M.N. $(\mathrm{eds})$ : Turning the tide: the eradication of invasive species. Proceedings of the International Conference on Eradication of Island Invasives. Occasional Paper of the IUCN Species Group Survival Commission No. 27, IUCN, Gland, Switzerland: 319-329.

Townrow, K. 1988: Sealing sites on Macquarie Island: an archaeological survey. Papers and Proceedings of the Royal Society of Tasmania 122: 15-25.

Trathan, P.N. \& Reid, K. 2009: Exploitation of the marine ecosystem in the sub-Antarctic: historical impacts and current consequences. Papers and Proceedings of the Royal Society of Tasmania 143: 9-14.

Tréhen, P., Frenot, Y., Lebouvier, M. \& Vernon, P. 1990: Invertebrate fauna and their tole in the degradation of cattle dung at Amsterdam Island. In Kerry, K.R. \& Hempel, G. (eds): Antartic Ecosystems. Ecological Change and Conservation. Springer, Berlin, Heidelberg: 337-346.

Turner, J., Colwell, S.R., Marshall, G.J., Lachlan-Cope, T.A., Carleton, A.M., Jones, P.D., Lagun, V., Reid, P.A. \& Jagovkina, J. 2004: The SCAR READER project: towards a high-quality data base of mean Antarctic meteorological observations. Journal of Climate 17: 2890-2898.

Vélain, C. 1877: Passage de Vénus sur le soleil, Expédition Française aux Iles St-Paul et Amsterdam. Zoologie. Observations générales sur la faune des deux îles, suivies d'une description des mollusques. Archives de Zoologie Expérimentale et Générale 6: 1-144.

Whinam, J. 2009: Aliens in the sub-Antarctic — biosecurity and climate change. Papers and Proceedings of the Royal Society of Tasmania 143: 45-51.

Whinam, J., Chilcott, N. \& Bergstrom, D.M. 2005. Subantarctic hitchhikers: expedirioners as vectors for the introduction of alien organisms. Biological Conservation 121: 207--219.

Woehler, E.J., Cooper, J., Croxall, J.P., Fraser, W.R., Kooyman, G.L., Miller, G.D., Nel, D.C., Patterson, D.L., Peter, H-U, Ribic, C.A., Salwicka, K., Trivelpiece, W.Z. \& Weimerskirch, H. 2001: A statistical assessment of the status and trends of Antarctic and subantarctic seabirds. Report on SCAR BBS Workshop on Southern Ocean Seabird Populations, Cambridge: 1-43.

(accepted 3 November 2009) 